\title{
A BÜNTETŐJOG JOGÁLLAMI KÖVETELMÉNYEI
}

\section{THE REQUIREMENTS OF CRIMINAL LAW BASED ON RULE OF LAW}

\author{
Belovics Ervin \\ egyetemi tanár, tanszékvezető, Pázmány Péter Katolikus Egyetem Jog-és Államtudományi Kar, Budapest \\ belovics.ervin@jak.ppke.hu
}

\begin{abstract}
ÖSSZEFOGLALÁS
A tanulmány a büntetőjog jogállami követelményrendszerének bemutatásával foglalkozik. A jogállami büntetőjog alapkérdései a rendszerváltást követően kerültek a figyelem középpontjába, és különösen az Alkotmánybíróság határozataiban jelentek meg azok az alapelvek, amelyeknek az érvényesülése elengedhetetlen feltétele a jog uralmának. A jogbiztonság-igazságosság konfrontációjának feloldása folyamatos feladatát képezte a rendszerváltást követően az Alkotmánybíróságnak. A tárgykörrel kapcsolatos büntetőjogi tárgyú döntéseket vizsgálva - elemezve a német joggyakorlatot is - a szerző egyet nem értésének ad hangot. A büntetőjog alapelveinek bemutatásakor sor kerül azok részletes elemzésére, illetve az elvekből fakadó következmények összefoglalására. Az írás befejező részében a szerző arra a kérdésre keresi a választ, ismérve-e a jogállamnak az az elvárás, hogy a polgárait másoktól megvédje, hogy a jogsértő magatartást kifejtő személyek cselekményeivel szemben is oltalmat nyújtson.
\end{abstract}

\section{ABSTRACT}

The study is focusing on the rule of law requirements for criminal substantive law. The fundamental aspects of the rule of law guarantees for criminal substantive law gained attention after the change in the political regime. It was in the resolutions of the Constitutional Court in particular where the basic principles that are the indispensable prerequisites of the rule of law started to appear. Resolving the confrontation between legal certainty and equity gave a permanent task for the Constitutional Court after the political changes. Upon examining decisions with criminal law aspects - as well as analysing the German legal practice - the author expresses his opinion of disagreement. Throughout the introduction of fundamental criminal law principles, the author analyses them in details and also synthesizes the consequences resulting from them. In the final part of the essay, the author is looking for an answer whether the expectations that governments should protect their citizens from others by providing legal shelter for them against the actions of unlawfully acting wrongdoers is a criterion of the rule of law principle.

Kulcsszavak: analógia tilalma, jogállami büntetőjog, jogbiztonság, jogos védelem, igazságosság, ex tunc hatály, ultima ratio

Keywords: prohibition of analogy, rule of law guarantees in criminal law, legal certainty, justifiable defence, equity, retroactive force (ex tunc temporal scope), ultima ratio 


\section{BEVEZETÉS}

A jogállam mint fogalom a 19. század első felében a német jogirodalomban (például Friedrich Julius Stahl, Karl Welcker, Rudolf von Gneist, Robert von Mohl munkáiban) jelent meg, és a diktatúrát jelképező rendőrállam ellentéteként azt kívánta kifejezésre juttatni, hogy a hatalmi struktúrát - beleértve az állam szerveinek müködését is - a jognak kell uralnia. Ebben a felfogásban tehát a jogállam alapvető kritériumát az képezi, hogy a hatalom is köteles a jogszabályokban meghatározott rendelkezéseket betartani, illetve, hogy a müködését elöre láthatóvá és kiszámíthatóvá kell tennie, valamint biztosítania kell a polgárok jogainak érvényesülését. Megjegyzem az Albert Venn Dicey által, a ma is használatos jelentéstartalommal felruházott angol rule of law elve (Venn Dicey, 1902) ugyancsak a jog uralmának kizárólagosságát jeleníti meg, azonban a common law sajátosságaira figyelemmel a büntetőjog területén a Rechtsstaat fogalmából egészen más követelmények származnak. Ezért indokolt a kontinentális jogfejlődés körében a büntetőjogi tézisekkel összefüggésben a német jogirodalom tételrendszerének az alapulvétele.

\section{JOGÁLLAMI BÜNTETŐJOGI KÖVETELMÉNYEK AZ ÁLLAM ÉS A POLGÁROK RELÁCIÓJÁBAN}

A 19. század második felére kialakuló és az állami szervek által biztosított rend utáni elvárások helyébe a polgárság eszmevilágában egyre inkább az állam közhatalmi jogosítványait korlátozni kívánó szabadság utáni vágy lépett. Mindebből következően a jogállam fogalma „,az állam és az állampolgár relációban érvényesül, a jogállamnak nem ismérve, hogy egyes állampolgárait, más állampolgárok ellenében megvédi. Nem jogállami ismérv, hogy az állam üldözi a tolvajokat és a rablókat, de jogállami ismérv, hogy biztosítja polgárai számára a véleménynyilvánítás és az információhoz hozzájutás szabadságát, az egyesülési és a gyülekezési szabadságot, a tulajdon biztonságát és szabadságát" (Békés, 2006). Arra a kérdésre, hogy a jogállam fogalmának leszúkítése az állam és a polgár kapcsolatára a büntetőjog területén változatlanul helytálló-e, a későbbiek során kívánok kitérni.

\section{A JOGÁLLAMI BÜNTETŐJOG ALAKI ÉS ANYAGI VETÜLETE}

Az Alkotmánybíróság megalakulásának kezdetétől fogva - de különösen müködésének első éveiben - kiemelt figyelmet fordított a jogállami büntetőjog kritériumrendszerének meghatározására.

Vizsgálódásai, illetve elemzései során - mivel egy korábbi diktatúra jogalkotási produktumainak mikénti megítélése újból és újból szükségessé tette az elvi jellegű állásfoglalást - központi szerepet töltött be a jogállami büntetőjog alaki és 
anyagi jellegủ összetevőjének a determinálása, a két tartópillér egymáshoz való viszonyának értékelése. Miként kapcsolódik egymáshoz a jogállam fogalmának egyik követelménye a jogbiztonság, azaz a pozitív írott jog által létrehozott jogrend, illetve az igazságosság, tehát, hogy a jog szabályainak meg kell felelnie a társadalom elvárásainak, az ész és az erkölcs kívánalmainak.

A kérdés akkor került fokozottan a figyelem középpontjába, amikor az Országgyülés 1991. november 4-én törvényt fogadott el egyes büncselekmények elévülési idejének ismételt elkezdődéséről. ${ }^{1}$

Az Alkotmánybíróság az Országgyưlés által elfogadott, de még ki nem hirdetett törvényt alkotmányellenesnek nyilvánította. ${ }^{2}$

Az Alkotmánybíróság okfejtése szerint „A jogállam alapvető eleme a jogbiztonság. A jogbiztonság - többek között - megköveteli a megszerzett jogok védelmét, a teljesedésbe ment, vagy egyébként véglegesen lezárt jogviszonyok érintetlenül hagyását, illetve a múltban keletkezett, tartós jogviszonyok megváltoztathatóságának alkotmányos szabályokkal való korlátozását [...] Az egyes jogviszonyok és jogi tények ugyanis önállósulnak az alapul fekvő normától, és annak sorsát nem osztják automatikusan. Ellenkező esetben minden jogszabályváltozás a jogviszonyok tömegének felülvizsgálatával járna. A jogbiztonság elvéből főszabályként az következik, hogy lezárt jogviszonyokat sem jogszabállyal, sem jogszabály hatályon kívül helyezésével - származzék ez akár a jogalkotótól, akár az Alkotmánybíróságtól - nem lehet alkotmányosan megváltoztatni.

Kivétel ez alól az elv alól csak akkor engedhető meg, ha azt a jogbiztonsággal konkuráló más alkotmányos elv elkerülhetetlenné teszi, és ezzel nem okoz céljához képest aránytalan sérelmet. Ilyen kivétel például a jogerősen lezárt büntetőeljárások felülvizsgálata az elítélt javára, ha az eljárás később alkotmányellenessé nyilvánított jogszabály alapján folyt. Ezt az alkotmányos büntetőjog követeli meg. A jogviszonyok igazságtalan eredménye viszont önmagában nem érv a jogbiztonsággal szemben. ${ }^{3}[\ldots]$ A lezárt jogviszonyok kímélete szempontjából nem le-

${ }^{1}$ A Zétényi Zsolt és Takács Péter országgyülési képviselők előterjesztése alapján elfogadott törvény szövege a következő: „1. § (1) 1990. május 2-án ismét elkezdődik az 1944. december 21-e és 1990. május 2-a között elkövetett, és az elkövetéskor hatályos törvényekben meghatározott azon büncselekmények büntethetőségének az elévülése, amelyeket az 1978. évi IV. tv. 144. § (2) bekezdése hazaárulásként, 166. § (1) és (2) bekezdése szándékos emberölésként 170. § (5) bekezdése halált okozó testi sértésként határoz meg, ha az állam politikai okból nem érvényesítette büntető igényét. (2) Korlátlanul enyhíthető az (1) bekezdés alkalmazásában kiszabott büntetés." A köztársasági elnök a törvényt nem hirdette ki, hanem az 1991. november 16-án kelt indítványában alkotmányossági vizsgálatát kérte.

2 11/1992. (III. 5.) AB határozat.

${ }^{3}$ Az Alkotmánybíróság a 9/1992. (I. 30.) AB határozatában kifejtettek szerint, ,,az anyagi igazságosság jogállami követelménye a jogbiztonságot szolgáló intézményeken és garanciákon belül maradva valósulhat meg. Az anyagi igazság érvényesülésére [...] nem biztosít (nem biztosíthat) alanyi jogot az Alkotmány." 
het különbséget tenni aszerint, hogy az alapul fekvő jogszabály miért és mikor lett alkotmányellenes. A törvényhozót minden jogviszonnyal kapcsolatban kötik a visszaható hatályú törvényhozás korlátai [...] Az alkotmányellenesnek nyilvánított jogszabályok által teremtett helyzetet a jövöre nézve, új jogalkotással lehet alkotmányosan orvosolni.

Nem lehet [...] a jogállam megkövetelte igazságosságra hivatkozva a jogállam alapvető biztosítékait félretenni. Jogállamot nem lehet a jogállam ellenében megvalósítani. A mindig részleges és szubjektív igazságosságnál a tárgyi és formális elvekre támaszkodó jogbiztonság előbbre való. [...] az alkotmányos büntetőjog alapintézményei legtöbb esetben fogalmilag sem relativizálhatók, s nem képzelhető el velük szemben mérlegelhető más alkotmányos jog vagy feladat. A büntetőjogi garanciák ugyanis már egy mérlegelés eredményét tartalmazzák, azt, hogy a bünüldözés sikertelenségének kockázatát az állam viseli. [...] Ezért az ártatlanság vélelmét már nem lehet más alkotmányos jog miatt korlátozni, de fogalmilag sem lehetséges nem teljesen érvényesíteni; az állam tétlensége folytán az elévülési idő leteltekor megszerzett büntethetetlenség az elévülés leteltének pillanatában teljesen beáll, és nem lehet utólag sem »csökkenteni«, sem feléleszteni; s nem lehet a nullum crimen sine lege feltételét sem például mások jogai védelmére irányuló valamely alkotmányos feladat ellátásával pótolni. [...] Büntetőjogi garanciák alóli kivétel fogalmilag is csak a garanciák nyílt félretételével lenne lehetséges, ezt azonban a jogállam elve kizárja. [...] A jogállam jogrendje senkitől sem tagadhatja meg a jogállami garanciákat. Ezek ugyanis alapjogként mindenkit megilletnek. Jogállami értékrend alapján jogállami garanciák mellőzésével még igazságos követelés sem érvényesíthető. Az igazságosság és az erkölcsi indokoltság lehet ugyan motívuma a büntetendőségnek, a büntetést érdemlőségnek, de a büntethetőség jogalapjának alkotmányosnak kell lennie. [...] jogállamban az államnak nincs és nem lehet korlátlan büntető hatalma. Mégpedig azért nem, mert maga a közhatalom sem korlátlan. Az alkotmányos alapjogok és alkotmányos védelmet élvező szabadságok miatt a közhatalom csak alkotmányos felhatalmazással és alkotmányos indokkal avatkozhat be az egyén jogaiba és szabadságába."4

Az Alkotmánybíróság ismertetett álláspontja tehát a jogállami büntetőjog formális elemének, azaz a jogbiztonság elvének mindenhatóságára hivatkozva semmisítette meg a büntetőjogi elévülési idő újrakezdődéséről szóló törvényt,

\footnotetext{
${ }^{4}$ Az idézett alkotmánybírósági határozatban, több más, ebben a korszakban született alkotmánybírósági döntéshez hasonlóan, megjelenik az „alkotmányos büntetőjog” Szabó Andrástól eredeztethető fogalma. Megítélésem szerint ennek a szóösszetételnek - bár a korszak jogtudósainak többsége nagy gyakorisággal használta - tartalmi jelentősége nincs, hiszen csak arra utal, hogy a büntetőjogi normáknak - miként minden más jogág, minden rendelkezésének - összhangban kell állnia az Alkotmány szabályaival.
} 
mely okfejtéssel egyetérteni nem lehet. Minden diktatúra determináló jellegü sajátossága, hogy a hatalom gyakorlóinak, valamint az egyeduralmi rendszer fenntartására hivatott klientúrának a felelősségre vonására még akkor sem kerül sor, ha tevékenységük ténylegesen kimeríti valamely büncselekmény törvényi tényállását, azaz ha magatartásuk büntetőjog-ellenes. A pozitív írott jogot, vagyis a jogbiztonságot az erodálja a leginkább, ha az arra egyébként köteles állami szervek elmulasztva cselekvési kötelezettségüket, lehetővé teszik egyes jogsértő személyek számára a felelősségre vonás előli menekülést. Tekintettel arra, hogy az ilyen rendszerekben a hatalmat gyakorló személyeknek a büntetőjogi felelősségre vonhatósága a diktatúra fennállásáig fogalmilag kizárt, ezért az önkényuralmi rendszer összeomlása után nem csupán az igazságosság követelménye teszi elengedhetetlenné a számonkérést, hanem a jogbiztonság helyreállítása is csak így valósulhat meg. Álláspontom szerint tehát a rendszerváltást követően a jogállami büntetőjog értékrendjével ellentétben álló módon maradt el a diktatúra időszakában büncselekményt megvalósító személyekkel szembeni eljárások megindítása.

Álláspontom alátámasztásaként kívánom megemlíteni, hogy a német egység létrehozása után a Német Demokratikus Köztársaság korábbi vezetőinek büntetőjogi felelösségre vonása semmilyen problémát nem okozott a német bíróságok, illetve a német Alkotmánybíróság számára. A német bíróságok ugyanis több magas rangú vezetőt szándékos emberölés miatt hosszabb tartamú szabadságvesztésre ítéltek a berlini falnál, illetve a „belnémet határon” elkövetett cselekményekkel összefüggésben, amikor is a határőrök a határt illegálisan átlépni kívánókkal szemben fegyvert használtak az „aki megsérti a határt, elveszíti az életét" parancs realizálása érdekében. Elítélésüket követően a terheltek a német Alkotmánybírósághoz fordultak. A német Alkotmánybíróság álláspontja szerint „A jogállami feltételek mellett létrejött büntetőjog elvileg megfelel a materiális igazságosság követelményének. Ez egy különleges bizalmi helyzetet alapoz meg, erre épül a visszaható hatály tilalma. Ez az alaphelyzet azonban megszünik, ha egy állam büntethetőséget kizáró okok létrehozásával semmibe veszi az általánosan elismert emberi jogokat, és a legsúlyosabb büntetőjogi igazságtalanságot idézi elö. Egy ilyen esetben a materiális igazságosság parancsát kell előnyben részesíteni, a visszaható hatály tilalmával szemben [...] A visszaható hatály tilalma nem érvényesül, ha egy állam súlyos büntetőjogi igazságtalanságok elkövetésére bíztatja a polgárait, és ezzel megsérti az általánosan elismert emberi jogokat" (Békés, 2004). Az elítéltek ezt követően az Emberi Jogok Európai Bíróságának eljárását kezdeményezték. A bíróság megállapította, hogy a német bíróságok nem sértették meg az Emberi Jogok Európai Egyezményét azzal, hogy „,az elkövetéskor hatályban volt NDK-beli szabályokat a jogállami alapelvek szerint értelmezték" (Békés, 2004). 
Az ismertetett döntésekből egyértelmüen kiderül, hogy a jogállami büntetőjog követelményrendszerének mindenben megfelelö módon felelősségre lehetett volna vonni azokat, akik az 1944 és 1990 közötti időszakban a legsúlyosabb büncselekményeket úgy valósították meg, hogy ellenük büntetőeljárás nem indult.

\section{A JOGÁLLAMI BÜNTETŐJOG ALAPELVEI}

\subsection{A legalitás elve}

A kontinentális jogrendszerben a büntető anyagi jog tekintetében kiemelkedő jelentőséggel bír a legalitás elve, figyelemmel arra, hogy az összes többi elvi tétel a legalitás elvére vezethető vissza. Az elv lényegét megjeleníti az Emberi jogok és az alapvető szabadságok védelméről szóló, Rómában, 1950. november 4-én kelt egyezmény és az ahhoz tartozó nyolc kiegészítő jegyzőkönyv kihirdetéséről szóló 1993. évi XXXI. törvény 7. cikke, amely szerint senki nem ítélhető el olyan cselekményért vagy mulasztásért, amely az elkövetés idején a hazai vagy a nemzetközi jog alapján nem volt büncselekmény, illetve nem lehet a büncselekmény elkövetése idején alkalmazható büntetésnél súlyosabb büntetést kiszabni. Megjegyzem a legalitás elve nem elengedhetetlen feltétele a jogállamiságnak „A precedens rendszer szerint épülő angolszász jogokban nincs minden büncselekményre írott törvény alkotva. Léteznek több száz éves precedensek is, az ekként »bíró alkotta jog« hatályosul a törvény helyett” (Békés, 2006).

2.1.1. A jogállami büntetőjog szempontjából determináló szerepe van az anyagi jogi legalitás egyik tételének, azaz a nullum crimen sine lege elvének. „Ha a büntetőjog-történetben visszamegyünk, akkor látható, hogy a tényállásszerüség Cristoph Carl Stübel és Anselm Feuerbach munkássága révén az 1800-as évek elején a nullum crimen sine lege elv következményeinek végiggondolása miatt lépett előtérbe. E pontosítás után a büntetni rendelt cselekmény nem úgy általában ütközik a jogrendbe, jogtalanságot megvalósítva, hanem csak ha ez pontosan a tényállásszerüen definiált, tiltott cselekményt valósít meg [...] Csak a tényállásszerüen megfogalmazott büncselekményekből álló büntetőjog felel meg a nullum crimen sine lege elvnek [...] Olyan szabad és laza szabályozás, mely pl: a magánjogban lehetséges - ahol a bíró tág mérlegelési keretek között mondhatja ki döntését - a büntetőjogban a nullum crimen-elv miatt nem elfogadható" (Pokol, 2016).

Az elv büntetöjogi következményei a következők:

- a nemzetközi ius cogens által büntetni rendelt cselekmények a belső jog rendelkezéseitől függetlenül alapozzák meg a büntetőjogi felelősséget,

- büncselekménnyé egy magatartást - tevékenységet vagy mulasztást - csak a belső jogforrási struktúra csúcsán álló jogi norma tehet, 
- a büncselekménnyé nyilvánításnak a cselekmény kifejtését megelőzően kell megvalósulnia,

- azért a magatartásért, amely a kifejtésekor nem volt büntetőjog-ellenes, büntetőjogi felelősséget megállapítani nem lehet,

- bủncselekményt kizárólag tényállásszerü cselekmény hozhat létre,

- a bíróság csak olyan magatartás miatt állapíthat meg büntetőjogi felelősséget, amely beleillik valamely deliktum törvényi tényállásába,

- amennyiben a cselekmény elbírálásakor hatályos új törvény szerint az eljárás tárgyát képező magatartás már nem büncselekmény, az új törvény alkalmazása kötelező.

2.1.2. Az anyagi jogi legalitás második tétele a nulla poena sine lege elve. „A törvény uralmának tipikus derivátuma az az elv, mely szerint »nincs büntetés törvény nélkül«, ami a kiszámíthatóság követelményének egy aspektusát veszi célba - azt, hogy elöre figyelmeztetni kell az embereket, hogy bizonyos fajta cselekedetek büntetést vonnak maguk után" (Aubert, 1993).

Az elv alaptézisei a következők:

- kizárólag a belső jogforrási struktúra csúcsán található jogi norma állapíthat meg büntetöjogi jogkövetkezményt,

- a bíróság csak olyan büntetőjogi jogkövetkezményt alkalmazhat, amelyet a törvény a deliktum megvalósítását megelőzően hozzárendelt a létrehozott büncselekményhez,

- a bíróság a joghátrány meghatározásakor köteles a kiszabott büntetés vagy alkalmazott intézkedés tekintetében a vonatkozó jogszabályi rendelkezések betartására, tehát ezek nemét, tartamát vagy mértékét csak úgy határozhatja meg, hogy az megfeleljen a jogszabály követelményeinek,

- amennyiben a cselekmény elbírálásakor hatályos új büntető norma szerint a magatartás súlyosabban büntetendő, az új törvény nem alkalmazható,

- amennyiben a cselekmény elbírálásakor hatályban lévő új büntető jogszabályra figyelemmel a cselekmény enyhébb megítélés alá esik, az új törvényt alkalmazni kell.

Megjegyzem, a nullum crimen sine lege, illetve a nulla poena sine lege elve „nem tartozik ugyan elválaszthatatlanul egybe, kialakulásuk mégis egybeesik" (Földvári, 2003).

\section{A SÚLYOSABB BÜNTETŐ RENDELKEZÉS VISSZAHATÓ HATÁLYÁNAK TILALMA}

A legalitás elvéből fakadó jogállami követelmény a kontinentális büntetőjogban a súlyosabb büntető rendelkezés visszaható hatályának a tilalma. A kontinentális jogrendszer jogállami büntetőjogi főszabálya, hogy bárkit csak az elkövetéskor ha- 
tályban lévő törvény szerint lehet felelösségre vonni és megbüntetni. ${ }^{5}$ Tehát a nullum crimen sine lege és a nulla poena sine lege elve egyértelmüen meghatározza az időbeli hatállyal kapcsolatos büntetöjogi rendelkezéseket is, ${ }^{6}$ ami - a klasszikus iskola tantétele szerint - ,abból az alapvető felfogásból indult ki, hogy a büncselekmény elkövetése idején a hatályos büntetőjogi norma rendelkezéseit az elkövető ismerte, de a törvény rendelkezéseivel ellentétes magatartást tanúsított [...] következésképpen viselnie kell a jogellenes magatartás hátrányos jogkövetkezményeit, még abban az esetben is, ha a cselekményének az elbírálása idején az elkövetéskor hatályos norma úgy változott meg, hogy a magatartás már nem büntetendő vagy az elkövetöre nézve előnyösebb rendelkezést tartalmaz" (Kiss, 2000). Az ex tunc hatály tilalma azonban ma már nem teljes körü, azaz a büntető jogszabály visszaható hatályú alkalmazása jogállamban sem tiltott, ellenkezőleg, kifejezetten követelményként jelentkezik, de csak akkor, ha az elbíráláskor a cselekmény már nem büncselekmény, vagy enyhébben bírálandó el. Amint arra az Alkotmánybíróság is rámutatott, „A visszaható hatály kifejezett tilalma mellett az elbíráláskori enyhébb szabály alkalmazásának elóírása a jogállamiság követelményéből fakad."7

Az ex tunc hatály tilalmával kapcsolatos általános jellegü alaptételek a következők:

- a büncselekményt annak elkövetése idején hatályban lévő büntetőtörvény szerint kell elbírálni, az utóbb bekövetkező változások indifferensek,

- nem lehet büntetöjogi felelösséget kimondani olyan magatartás miatt, amely a megvalósításakor nem volt büntetőjog-ellenes, és nincs lehetőség egy deliktum elkövetése miatt olyan - a büntető anyagi jogi norma által tartalmazottnál

\footnotetext{
${ }^{5}$ Az elv megsértésének klasszikus példája a „lex van der Lubbe” ügy. Az 1933. február 27-én felgyújtott német parlament épületének Bismarck-termében elfogott Marinus van der Lubbe a kihallgatása során a büncselekmény elkövetését elismerte. A Reichstag felgyújtásakor a szándékos gyújtogatásra a büntetőtörvény életfogytig tartó fegyházbüntetés kiszabását tette lehetővé. 1933. február 28-án Ludwig Grauert államtitkár szükségállapot bevezetését javasolta Poroszországban, amit Wilhelm Frick miniszter előterjesztésére az egész német birodalomra kiterjesztettek. Ennek jogi következménye az volt, hogy az addig életfogytig tartó fegyházbüntetéssel fenyegetett cselekmények tekintetében halálbüntetés kiszabása is lehetségessé vált. Az 1933. március 29-én hatályba lépett törvény a szükségállapoti rendelkezéseket kiterjesztette az olyan büncselekményekre is, amelyeket 1933. január 31. és 1933. február 27-e között valósítottak meg, mely rendelkezés alapján halálbüntetés kiszabására is lehetőség nyílt.

${ }^{6}$ Lásd az 1976. évi 8. törvényerejü rendelettel kihirdetett, az Egyesült Nemzetek Közgyűlése XXI. ülésszakán, 1966. december 16-án elfogadott Polgári és Politikai Jogok Nemzetközi Egyezségokmányának 15. cikkének 1. pontja, az 1993. évi XXXI. törvénnyel kihirdetett, az Emberi jogok és az alapvető szabadságok védelméről szóló, Rómában 1950. november 4-én kelt Egyezmény és az ahhoz tartozó nyolc kiegészítő jegyzőkönyv 7. cikke, Európai Unió Alapjogi Chartájának 49. cikke, Alaptörvény XXVIII. cikk 4. bekezdés.

7 11/1992. (III. 5.) AB határozat.
} 
súlyosabb - jogkövetkezmény alkalmazására, amely a büntetőjog-ellenes magatartás tanúsításakor még nem képezte részét a büntetőtörvénynek,

- a tilalom nem vonatkozik az elkövetést követően hatályba lépett azon normákra, amelyek megszüntetik a megvalósult cselekmény pönalizálását, valamint az enyhébb elbírálást lehetővé tevő jogszabályokra,

- csak látszólagosan jelentkezik a terhelt terhére az a tétel, amely szerint nem kizárt a büntetőeljárás megindítása és az elítélés olyan cselekmény miatt, amely az elkövetése idején kizárólag a nemzetközi jog általánosan elismert szabályai alapján minősül büncselekménynek, mivel a nemzetközi ius cogens - amint már említettem - a belső jog rendelkezéseitől függetlenül alapozza meg a büntetendőséget.

\section{A BÜNTETŐJOG ULTIMA RATIO JELLEGE}

A tétel azt a követelményt jeleníti meg, hogy a különbözö konfliktushelyzetek rendezésére elsődlegesen más jogágak normarendszerét kell igénybe venni. Másként fogalmazva a büntetöjogi fenyegetettség létrehozásának elengedhetetlen feltétele, hogy annak megteremtése szükséges legyen, azaz ne létezzen enyhébb módja a jog védelmének. Tekintettel arra, hogy a büntetőjog olyan joghátrány okozására is lehetőséget ad, amelyet egyetlen másik jogág sem tesz lehetővé, a büntetőjogi jogkövetkezmények igénybevételére csak akkor kerülhet sor, ha a más jogágak által biztosított jogvédelem nem elégséges eszköze a jogrend oltalmazásának. Tehát „A büntetőjog a jogi felelősségi rendszerben az ultima ratio. Társadalmi rendeltetése, hogy a jogrendszer egészének szankciós zárköve legyen. A büntetőjogi szankció a büntetés szerepe és rendeltetése a jog és erkölcsi normák épségének fenntartása, akkor, amikor már más jogágak szankciói nem segítenek [...] tartalmi követelmény, hogy a törvényhozó a büntetendő magatartások meghatározásakor nem járhat el önkényesen. Valamely magatartás büntetendővé nyilvánításának szükségességét szigorú mércével kell megítélni; a különböző életviszonyok erkölcsi és jogi normák védelmében az emberi jogokat és szabadságokat szükségképpen korlátozó büntetöjogi eszközrendszert csak a feltétlenül szükséges esetben és arányos mértékben indokolt igénybe venni, akkor, ha az alkotmányos vagy az alkotmányra visszavezethetô állami, társadalmi, gazdasági célok, értékek megóvása más módon nem lehetséges." 8

Az ultima ratio jellegből fakadó jogállami elvárások tehát, hogy

- a társadalom életében megvalósuló konfliktushelyzetek feloldására elsősorban a büntetöjogon kívüli jogágak hivatottak,

- jogsértés esetén a más jogágak által szabályozott joghátrányok alkalmazása által kell biztosítani a jogépséget,

8 30/1992. (V. 26.) AB határozat. 
- büntetőjog-ellenessé csak az olyan magatartás nyilvánítható, amelynek esetében a büntetőjogi védelem megteremtése elkerülhetetlen,

- a büntetőjogi fenyegetettségnek arányban kell állnia a büntetőjog-ellenessé nyilvánított magatartás absztrakt társadalomra veszélyességével.

Mindezek a követelmények a jogalkotó felé azt jelenítik meg, hogy a büntetőjogi jogalkotás sem a büntetendővé nyilvánítás, sem a büntetőjogi jogkövetkezmények meghatározása során nem lehet önkényes. Nem lehet tehát korlátlanul bővíteni a büncselekmények körét még akkor sem, ha olykor a regnáló hatalom a nem kívánt magatartás büncselekménnyé nyilvánításában látja a probléma megoldásának egyetlen lehetséges módját. Abban az esetben, ha a jogalkotó mégis ezt teszi, nem csupán megsérti az ultima ratio elvét, de azáltal, hogy csekély súlyú cselekményeket is büncselekménnyé nyilvánít, elértékteleníti a büntetőjogi szabályozást. A jogalkotás során ugyanakkor a szükségesség mellett az arányosság követelményére is tekintettel kell lenni, tehát amennyiben a büntetőjogi kodifikáció elengedhetetlenné válik a jogalkotónak a büncselekmény társadalomra veszélyességére figyelemmel kell meghatároznia a deliktum elkövetőjével szemben kiszabható jogkövetkezményt. Ez utóbbi követelményt egyébként a konkrét ügy elbírálásakor a jogalkalmazónak is érvényesítenie kell. „A büntetőtörvénynek a büntetés kiszabására vonatkozó szabályait olyan koherens rendszerként kell értékelni, amelyben az erre vonatkozó normák egymásra tekintettel és egymást kiegészítve alkalmazandók. Alkotmányossági szempontból a büntetéskiszabás normatív előírásainak az a rendeltetése, hogy lehetővé tegyék az elkövetőkre az arányos és a bünösségi körülményekkel összhangban álló büntetések kiszabását." ${ }^{\prime 9} \mathrm{Az}$ arányosság követelményének tehát a generál prevenciót segítő absztrakt társadalomra veszélyesség körében, illetve a speciál prevenciót szolgáló individualizáció tekintetében egyaránt szerepe van.

\section{A BÜNTETŐTÖRVÉNY EGYÉRTELMÜSÉGÉNEK KÖVETELMÉNYE}

A norma meghatározottságának fontossága már Cesare Beccaria munkáiban megjelenik, mert amint azt kifejti, „Minél nagyobb azoknak a száma, akik megértik és forgatják a törvények szent könyvét, annál kisebb lesz a büncselekmények száma, mert kétségtelen, hogy a büntetések nem ismerése és bizonytalansága segítik a szenvedélyek rábeszélő erejét” (Beccaria, 1967). A törvényeket „forgatni” azonban csak akkor lehet, ha azok megismerhetők. „Az előreláthatóság a legfontosabb követelmény, amit egy normának teljesíteni kell. Az előreláthatóság első feltétele a hozzáférhetőség, azon belül a fizikai hozzáférhetőség” (Gellér, 2008). Alapvetö jogállami büntetőjogi követelmény, hogy a büncselekmény törvény által legyen meghatározva, miként az is, hogy a jogalkotónak a büncselekménnyé

${ }^{9}$ 13/2002. (III. 20.) AB határozat. 
nyilvánítás során a tilalmazott vagy az elvárt magatartást a lehető legpontosabban úgy kell definiálnia, hogy azok bárki által követhetők legyenek, a jogszabály „legyen pontos, jól értelmezhető” (Kónya, 2017). A normaadekvát magatartás tanúsításának ugyanis elengedhetetlen feltétele a normavilágosság követelményének való megfelelés, tehát az, hogy a norma tartalma az értelmezés valamely fajtájának a segítségével egyértelmüen feltárható legyen. A határozott normaalkotás jogállami követelményéből fakad, hogy a jogszabályoknak egyértelmünek, ellentmondásoktól mentesnek és közérthetőnek kell lenniük, azaz a kodifikáció során arra kell törekedni, hogy a büntetőjogi rendelkezések megfogalmazására egyszerüen, a magyar nyelvszabályokra figyelemmel kerüljön sor. Ezzel azonos súlyú követelmény a pontos terminológiai egység, azaz a terminus technicusok precíz definiálása. Amennyiben a büntetőjogi tilalom vagy elvárás megfogalmazása érthetetlen, pontatlan, többfajta, esetleg egymásnak ellentmondó jelentéstartalommal bír, a norma címzettjei nem tudják eldönteni, hogy mi az elvárt, illetve követendő magatartás. A jogállami büntetőjog elvárásai szerint tehát ,a büntetőjogi szankciók kilátásba helyezésével tilalmazott magatartást leíró diszpozíciónak, határozottnak, körülhatároltnak, világosan megfogalmazottnak kell lennie. Alkotmányossági követelmény a védett jogtárgyra és az elkövetési magatartásra vonatkozó törvényhozói akarat világos kifejezésre juttatása. Egyértelmü üzenetet kell tartalmaznia, hogy az egyén mikor követ el büntetöjogilag szankcionált jogsértést. Ugyanakkor korlátoznia kell az önkényes jogértelmezés lehetőségét a jogalkalmazók részéről. Vizsgálni kell tehát, hogy a tényállás a büntetendő magatartások körét nem túl szélesen jelöli-e ki, és elég határozott-e."10

\section{AZ ELKÖVETŐ TERHÉRE ALKALMAZOTT ANALÓGIA TILALMA}

Az analógia tilalma a jogállami büntetőjog egyik alaptétele. Számos szerző (például Földvári József, Kádár Miklós, Kálmán György) teljeskörủen elveti az analógia alkalmazhatóságát, valójában azonban az analógia csak akkor sérti a jogállami követelményeket, ha azt a maga teljességében valamely büncselekmény törvényi tényállásába nem illeszkedő magatartásra alkalmazzák. ${ }^{11}$ Ilyenkor ugyanis tényle-

10 30/1992. (V. 26.) AB határozat.

${ }^{11}$ A szovjet büntetőtörvénykönyv tette a bűncselekmény fogalmi ismérvévé a társadalomra veszélyesség fogalmát azzal, hogy a társadalomra veszélyes magatartás nyilvánvalóan sérti a büntető anyagi jogot is. „Felmerülhet olyan eset, amikor valamely társadalomra veszélyes cselekmény nem meríti ki a Büntető Törvénykönyv egyik szakaszát sem, noha a megváltozott körülmények között társadalomra veszélyessége olyan fokot ér el, amely már büntetőjogi büntetés alkalmazását tenné szükségessé. Ebben az esetben a szovjet szocialista büntetőjog lehetővé teszi az analógia alkalmazását, vagyis a nem (törvényi) tényállásszerü cselekmény fajához és súlyához képest leginkább hasonló tényállásszerü cselekmény büntetőjogi következményei kerülnek alkalmazásra." 
gesen létezik egy jogilag szabályozott és egy jogilag nem szabályozott szituáció, a jogi analógia által pedig a jogalkalmazó a determináló jellegű elemek azonossága alapján a másodlagos körülmények eltérése ellenére egy norma hatályát kiterjeszti a norma, azaz a jog által nem szabályozott tevékenységre. „Mindez azt jelenti, hogy bár a jogalkalmazó tisztában van a jogszabályban megjelenő jogalkotói akarattal, illetve azzal, hogy a jogalkotó akarata a kialakult szituációra minden kétséget kizáróan nem terjedt ki, az adott jogszabályt a szabályozatlanul hagyott életviszonyra mégis alkalmazza. Lényegében tehát a jogalkalmazó kiterjesztő értelmezést valósít meg. A kontinentális jog által elismert és értékesített nullum crimen sine lege, valamint a nulla poena sine lege elvéből fakadóan azonban a büntető anyagi jog körében a büntetőjogi felelősség megállapítását vagy a büntetöjogi felelősség körének bővülését eredményező analógia alkalmazása fogalmilag kizárt.” (Belovics, 2017)

\section{A NE BIS IN IDEM ELVE}

A kétszeres értékelés tilalmát deklaráló tétel a tág értelemben vett büntetőjog minden területére, azaz a büntető anyagi jogra, a büntetőeljárás jogra, illetve a büntetés-végrehajtási jogra egyaránt kihat. Az anyagi büntetőjog körében azt a követelményt jeleníti meg, hogy a jogalkotó által egyszer már értékelt körülményt a jogalkalmazó nem vonhatja mérlegelési körébe. İgy például a büntetés kiszabása során nem lehet enyhítő tényezőként értékelni azt a tényt, ami megalapozza a privilegizált esetet, de súlyosító sem lehet az elkövetésnek olyan módja, ami viszont létrehozza a minősített esetet. A kétszeres értékelés tilalma tehát annak a megakadályozására hivatott, hogy bármilyen egyszer már értékelési körbe vont ténynek vagy körülménynek ismételten jelentőséget tulajdonítsanak.

\section{JOGÁLLAMI BÜNTETŐJOGI KÖVETELMÉNYEK A POLGÁROK RELÁCIÓJÁBAN}

Az eddig bemutatott tételek azon az elméleti kiindulóponton alapulnak, amely szerint a jogállami büntetőjog követelményrendszerének az állam és az állampolgár kapcsolatában kell érvényesülnie, azaz, hogy a jogállamnak nem ismérve, hogy pol-

(Kádár, 1953) Ugyanerre a következtetésre jut az 1949-ben készült tankönyv szerzöje, aki szerint „A szovjettörvény csak ritka kivétel alakjában (OSZSZT Btk. 16. §) fogadja el a büntetőtörvény analógiaszerủ alkalmazását, oly cselekvőségek viszonylatában, melyek közvetlenül, vagyis valamennyi részletükben nem nyertek meghatározást a büntetőtörvénykönyv különös részében. Ahhoz, hogy valamely cselekmény analógia alapján bünösnek és büntetendőnek minősüljön, három körülmény együttes fennforgása szükséges: 1 . az elkövetett cselekvőség társadalomra-veszélyessége; 2. hogy a büntetőtörvénykönyv semmilyen szakasza se tartalmazza az elkövetett cselekvőség meghatározását; 3 . hogy a büntetötörvénykönyv magában foglaljon oly szakaszt, mely fajára és fontosságára nézve a büncselekményhez hasonlót tartalmaz." (Durmanov, 1949) 
gárait másoktól megvédje, hogy a jogalkotás, illetve a jogalkalmazás körében a jogsértő magatartást kifejtő személyek cselekményeivel szemben is oltalmat nyújtson. Álláspontom szerint addig, amíg a XIX. század végén Európa nyugati felén, Közép-Kelet Európában pedig a XX. század végéig a hatalmi struktúrát diktatórikus vonások jellemezték, a jogállamiság hangsúlyainak az állam és a polgárok relációjára való vonatkoztatása elengedhetetlen volt. A társadalmi-politikai változások eredményeként azonban napjainkban a jogállami büntetöjog feladatkörébe tartozónak kell tekinteni annak védelmi funkcióját is, azaz, hogy a büntetőjognak oltalmaznia kell a fennálló társadalmi, gazdasági, állami rendet, a polgárok személyét és jogait.

Ugyanerre a következtetésre jutott már a múlt század közepén több európai jogtudós is. Így a jogállam egyik tartópillérének, azaz a jogbiztonságnak (rettsskkerhet) a fogalmi elemzésekor a norvég Johs Andenaes annak a véleményének adott hangot, hogy „A rettsskkerhet vonatkozásában két dologra kell gondolnunk. Először is az egyéni jogok más állampolgárokkal szembeni védelmére. Másodszor az állam hatalmának önkényes használatával vagy az ezzel való visszaéléssel szembeni védelemre" (Andenaes, 1945). Amint azt Vilhelm Aubert megjegyzi, „A büntetőjogász számára természetes, hogy az élet és a tulajdon védelmét a törvénytelen támadásokkal szemben szintén ide számítsa" (Aubert, 1993).

Mindez azt jelenti, hogy a Büntető Törvénykönyv különös részi törvényi tényállásai le kell, hogy fedjék az említett értékeket, illetve érdekeket veszélyeztető vagy sértő magatartásokat, illetve, hogy az államnak arra az esetre, ha nem képes megvédeni polgárát, biztosítani kell a védekezés jogát. Az utóbbi kereteinek a meghatározása kiemelkedő jelentőséggel bír, mert ebben a körben tehető egyértelmüvé, hogy a jogalkotó a jogellenes magatartást tanúsító vagy az ilyen magatartás elhárítására törekvő személy érdekeit kívánja-e oltalmazni.

Egyértelműen leszögezhető, hogy az új Büntető Törvénykönyv, azaz a 2012. évi C. törvény (továbbiakban: Btk.) jelentős mértékben újította meg a jogos védelem szabályrendszerét, miközben fenntartotta a korábbi Büntető Törvénykönyv ${ }^{12}$ hatályban létének utolsó fázisában beillesztett rendelkezéseket. Az utóbbi körbe tartozik a megelőző jogos védelem, ${ }^{13}$ a beszámítást kizáró ok szabályozásának kiszélesítése, illetve annak kimondása, hogy a megtámadott nem köteles kitérni a támadás elől. Különösen az utóbbi rendelkezésnek volt jelentős gyakorlati kihatása, mert a Legfelsőbb Bíróság 15. számú irányelvén alapuló bírói jogalkalmazás menekülési kötelezettséget írt elő a megtámadott számára bizonyos esetekben. Így menekülési kötelezettség terhelte a lemenőt a felmenő, a testvért a testvér, valamint a házastársat a házastárs támadásával szemben. Ugyanilyen kötelezettség állt fenn, ha a támadó szemmel láthatóan tudatzavarban volt. Mindez azt jelentette, hogy amennyiben a megtámadott a kitérési kötelezettségének az ilyen szemé-

${ }^{12}$ A Büntető Törvénykönyvröl szóló 1978. évi IV. törvény.

${ }^{13}$ Btk. 21. §. 
lyek támadása esetén annak ellenére nem tett eleget, hogy a menekülési lehetösége fennállt, a támadást elhárító magatartásért felelősség terhelte. A Legfelsőbb Bíróság említett irányelvében megjelenítettek - anélkül, hogy annak bármilyen jogszabályi alapja lett volna - a büntetőjog-ellenes magatartást kifejtőket voltak hivatva oltalmazni, és contra legem szúkítették a védekezés jogát, törvénysértő módon bővítve ezáltal a büntetőjogi felelösség körét. Annak a jogszabályban való megjelenítése, hogy a megtámadottat menekülési kötelezettség nem terheli, a bemutatott törvényrontó jogalkalmazói gyakorlatot számolta fel.

A Btk. legjelentősebb újdonsága az úgynevezett szituációs jogos védelem, ${ }^{14}$ mely rendelkezéssel a jogalkotó egy megdönthetetlen vélelmet állított fel, kimondva, hogy bizonyos esetekben a jogtalan támadást úgy kell tekinteni, mintha az a védekező életének a kioltására irányult volna. Mindez azt jelenti, hogy a jogalkalmazónak a konkrét ügy felderítése során kizárólag a Btk.-ban meghatározott feltételek fennállását kell tisztáznia, és azok létezésekor nincs lehetősége semmilyen mérlegelésre, illetve értékelésre. „Így amennyiben adottak a jogalkotó által megkívánt körülmények, indifferenssé válik a konkrét szituáció két legfontosabb sajátossága, vagyis a támadás tényleges irányultsága és a védelmi cselekmény terjedelme. A jogtalan támadás ab ovo élet elleni támadássá nyilvánítása ugyanis jogszerűvé teszi az élet kioltásával járó magatartást akkor is, ha a konkrét helyzet ilyen elhárítást nem tett szükségessé." (Belovics, 2017) A Btk.-ban szereplő esetekben ,a törvény az erőszakos büncselekmények elleni hatékonyabb fellépés biztosítására a jogos védelmi helyzetet kiszélesítette, és a támadás irányultságára, idejére, módjára, körülményeire tekintettel törvényi vélelmet állított fel arra, miszerint a megkívánt feltételek mellett a támadást a védekező élete ellen irányultnak kell tekinteni. A jogalkotó a jogellenes cselekmények sértettjeinek helyzetét figyelembe véve értékelte azt, hogy a jogtalanul megtámadottak a támadóhoz képest többszörös hátrányban vannak, mert a támadott dönti el, a támadás célját, helyét, idejét, módját. A védekezőt mindez felkészületlenül éri, és ezért az esetek többségében kiszolgáltatott helyzetben van. Ellenszegülésének sikere is kétséges,

\footnotetext{
${ }^{14}$ Btk. 22. § (2) A jogtalan támadást úgy kell tekinteni, mintha az a védekező életének kioltására is irányult volna, ha

a) azt személy ellen

aa) éjjel,

ab) fegyveresen,

ac) felfegyverkezve vagy

ad) csoportosan követik el,

b) az a lakásba

ba) éjjel,

bb) fegyveresen,

bc) felfegyverkezve vagy

bd) csoportosan történő jogtalan behatolás, vagy

c) az a lakáshoz tartozó bekerített helyre fegyveresen történő jogtalan behatolás.
} 
sőt olykor kimenetele csupán a véletlenen, a szerencsén múlik. Különösen igaz ez azokban az esetekben, amikor a jogtalan támadás éjjel, felfegyverkezve, fegyveresen vagy létszámfölényben lévő támadók által történik."15

\section{ÖSSZEGZÉS}

A jogállami büntetőjog alapvető jellemzője tehát, hogy érvényesülnek azok az elvek, amelyeknek létezését az állam szerveinek, így különösen a törvényhozásért, valamint a jogalkalmazásért felelős szerveknek garantálniuk kell. Ezek az alapelvek keretek közé szorítják a jogalkotást, és gátját képezik a bírói önkénynek. A 21. századi viszonyok között azonban a jogállamiság már nem csupán a törvényhozói és a bírói hatalom korlátozására hivatott, hanem a védelmi funkciónak a polgárok egymás közötti kapcsolatában is érvényesülnie kell.

\section{IRODALOM}

Andenaes, J. (1945): Grunnlov og rettsskkerhet. Michelsens Insitut, Bergen

Aubert, V. (1993): A jogállam. Jogállam, 1, 62.

Beccaria, C. (1967): Büntett és büntetés. (ford. Sebestyén P.) Budapest: Akadémiai Kiadó

Békés I. (2004): Az Emberi Jogok Európai Bíróságának ítélete a Streletz, Kessler és Krenz kontra Németország elleni ügyben. In: Gellér B. (szerk.): Ünnepi kötet Györgyi Kálmán 75. születésnapja alkalmából. Budapest: KJK-KERSZÖV Jogi és Üzleti Kiadó Kft. http://www.eltereader. hu/kiadvanyok/unnepi-kotet-gyorgyi-kalman-70-szuletesnapja-alkalmabol/

Békés I. (2006): Büntetőjog. Budapest: HVG ORAC Lap- és Könyvkiadó Kft.

Belovics E. (2017): Büntetőjog I. Budapest: HVG ORAC Lap- és Könyvkiadó Kft.

Durmanov, N. D. (1949): A szovjet büntetöjog alapelvei. (ford. Tardy L.) Budapest: Hírlap, Szaklap és Könyvkiadó Rt.

Földvári J. (2003): Magyar Büntetöjog. Budapest: Osiris Kiadó

Gellér B. J. (2008): A magyar büntetöjog tankönyve I. Általános tanok. Budapest: Magyar Közlöny Lap- és Könyvkiadó

Kádár M. (1953): Magyar büntetőjog. Általános Rész. Budapest: Tankönyvkiadó

Kiss Zs. (2000): A visszaható erő kérdései a büntetőtörvény időbeli hatályával kapcsolatos rendelkezések tükrében. In: Busch Béla (szerk.): Békés Imre ünnepi kötet. Budapest: Pázmány Péter Katolikus Egyetem Jog- és Államtudományi Kar

Kónya I. (2017): Az állam büntetőhatalma. In: Barabás A. T. - Vókó Gy. (2017): A bonis bona discere. Ünnepi kötet Belovics Ervin 60. születésnapja alkalmából. Budapest: OKRI-PPKE JÁK, http://mek.oszk.hu/18600/18609/18609.pdf

Pokol B. (2016): Büntetőjogelméleti vizsgálódások. Budapest: Rejtjel Kiadó

Venn Dicey, A. (1902): Bevezetés az angol alkotmányjogba. (ford. Tarnai J.) Budapest: Magyar Tudományos Akadémia

15 4/2013. Büntető jogegységi határozat. 